\title{
STRUCTURING POTENTIAL OF COVER CROPS IN A CLAYEY OXISOL AND THEIR EFFECT ON CRAMBE GRAIN YIELD AND OIL CONTENT
}

\author{
Potencial estruturante de espécies de cobertura em Latossolo argiloso e seus reflexos no rendimento de grãos e de óleo do crambe \\ Helton Aparecido Rosa ${ }^{1 *}$, Deonir Secco ${ }^{2}$, Reginaldo Ferreira Santos ${ }^{3}$, Araceli Ciotti de Marins ${ }^{4}$, Carlos Henrique \\ Fornasari $^{5}$, Gustavo Veloso ${ }^{6}$
}

\author{
1Docente: Curso de Agronomia; Centro Universitário Assis Gurgacz; helton@fag.edu.br* \\ 2Docente: Programa de Mestrado em Engenharia de Energia na Agricultura; Universidade Estadual do Oeste do Paraná; \\ deonir.secco@unioeste.br \\ 32Docente: Programa de Mestrado em Engenharia de Energia na Agricultura; Universidade Estadual do Oeste do Paraná; \\ reginaldo.santos@unioeste.br \\ 4Docente: Universidade Tecnológica Federal do Paraná, Toledo - PR - Brasil. araceli@utfpr.edu.br \\ ${ }^{5}$ Engenheiro Agrônomo; Agronómico, Hernandarias, Paraguay. \\ ${ }^{6}$ Engenheiro Agrícola; Compania Nacional de Abastecimento - Curitiba - PR - Brasil. veloso_g@hotmail.com
}

Artigo enviado em 16/03/2017, aceito em 19/09/2017 e publicado em 10/04/2018.

\begin{abstract}
This study aimed to assess the potential of twelve cover crops in improving the structural state of the soil evaluating soil bulk density and soil resistance to penetration and their effects on crambe grain yield and oil content. The experiment was conducted at the Experimental Center of Agricultural Engineering (NEEA), at the State University of West Paraná (UNIOESTE) - Cascavel - Paraná. The cover crops were named as treatments and consisted of twelve species, namely: Crotalaria juncea, Crotalaria spectabilis, Pigeon pea, Jack bean, Foxtail millet, Forage sorghum, Lablab beans, Guandu beans, Mucuna aterrimum, Mucuna Pruriens, Mucuna deeringiana, Mucuna aterrima, and a control treatment (fallow area). The experimental design used consisted of randomized blocks with four replications and plots measuring $5 \times 5 \mathrm{~m}$. When species were in full bloom in May 2010, they were managed by desiccation with non-selective herbicide and subsequent mowing in order to accelerate the decomposition rate of their roots. In August 2011 we performed the planting of crambe for further analysis of its grain and oil yield. In January 2012 soil samples were collected to evaluate soil bulk density by the volumetric ring method at depths of $0.0-0.1,0.1-0.2$ and $0.2-0.3 \mathrm{~m}$. Soil resistance to penetration was determined using a penetrometer until $0.4 \mathrm{~m}$ deep. In order to determine crambe grain yield, crambe was collected in an area of $4 \mathrm{~m}^{2}$ in the central part of each plot. In ordet tor determe seed oil content it was used the Soxhlet method. The statistical analyzes for soil variables (soil penetration density and resistance) and plant (grain yield and oil yield) consisted of analysis of variance (ANOVA), with a comparison test of mean values. It was also performed linear regression analyzes between data concerning to grain yield and oil yield, as well as grain yield and bulk density. The species Crotalaria spectabilis and Mucuna aterrima provided a significant reduction in soil bulk density when compared to the fallow area, showing higher structuring potential than other species after the first year of use. Considering the structural state of the soil prior to the experiment, with bulk density values lower than $1.2 \mathrm{Mg} \mathrm{m}^{-3}$, there was no significant effect on soil structure by any of the coverage species used and there was also no beneficial effect on crambe grain yield and oil content.
\end{abstract}

Keywords - soil structure, soil density, soil resistance to penetration.

Resumo - Este trabalho teve por objetivo avaliar o potencial de doze espécies de cobertura na melhoria do estado estrutural, através de avaliações da densidade e resistência do solo à penetração e seus reflexos no rendimento de grãos e de óleo da cultura do crambe. O experimento foi realizado no Núcleo Experimental de Engenharia Agrícola (NEEA), da Universidade Estadual do Oeste do Paraná (UNIOESTE) - Cascavel - Paraná. As espécies recuperadoras foram denominadas tratamentos e consistiram de doze espécies, sendo elas: crotalaria juncea, crotalaria spectabilis, feijão guandú, feijão de porco, capim moha, sorgo forrageiro, feijão lab-lab, guandú anão, mucuna preta, mucuna cinza, mucuna anã e mucuna verde, além da testemunha (área de pousio). O delineamento experimental utilizado foi o de blocos ao acaso com 4 repetições e parcelas experimentais de $5 \times 5 \mathrm{~m}$. Quando as espécies se encontravam em pleno florescimento, em maio de 2010, foram manejadas via dessecação, com o uso de herbicida de ação total, com posterior roçada, de forma a acelerar a velocidade de decomposição de suas raízes. Em Agosto de 2011 realizou-se o plantio de crambe para posterior análise do seu rendimento de grãos e de óleo. Em Janeiro de 2012, realizaram-se as coletas de amostras de solo, para avaliações de densidade do solo (Ds) pelo método do anel volumétrico, nas profundidades de 0,0-0,1; 0,1-0,2 e 0,2- 
0,3m. A resistência do solo à penetração (Rs) foi determinada através de um penetrômetro, até $0,4 \mathrm{~m}$ de profundidade. Para determinação do rendimento de grãos, colheu-se na parte central de cada unidade experimental uma área de $4 \mathrm{~m}^{2}$. Para a determinação do teor de óleo nas sementes, foi utilizado o método Soxhlet. As análises estatísticas para variáveis de solo (densidade e resistência do solo à penetração) e de planta (rendimento de grãos e de óleo) consistiram de análise de variância (ANOVA), com posterior teste de comparação de médias. Também foram realizadas análises de regressão linear entre os dados de rendimento de grãos e rendimento de óleo, rendimento de grãos e densidade do solo. As espécies Crotalaria Spectabilis e Mucuna verde apresentaram redução significativa de Ds em comparação à área de pousio, mostrando potencial estruturante superior às demais espécies após o primeiro ano de uso. Para o estado estrutural que o solo se encontrava, com valores de densidade inferiores a $1,2 \mathrm{Mg} \mathrm{m}^{-3}$, não houve efeito significativo sobre a estrutura do solo por nenhuma das espécies de cobertura utilizada, bem como não houve efeito benéfico sobre o rendimento de grãos e de óleo do crambe.

Palavras-Chave - estrutura do solo, densidade do solo, resistência do solo a penetração.

\section{INTRODUCTION}

For a good crop development, soil should fully perform its duties, such as supporting the growth of roots to allow plant development, which is its most important function. Among the main physical characteristics of a soil is its structure, which is directly linked to physical attributes such as bulk density, soil porosity and soil resistance to penetration, which are responsible for water infiltration and may reflect on the development of roots and plants.

Soil bulk density (Bd) is an important physical attribute of soil, as it provides information about the condition of its structure and especially because of its influence on properties such as infiltration and water retention in soil, root development, gas exchange and susceptibility of the soil to erosion. It is also widely used in the evaluation of compression and/or densification of soil (GUARIZ et al., 2009).

Data of soil resistance to penetration (SPR) have long been used over the years in numerous applications in different areas of agricultural research. Many of them have already been established, such as the detection of layers with greater state of resistance, the study of the effects of machinery use on soil, the prevention of hindrance on the development of plant root system, prediction of the necessary traction force for the execution of work and for providing information on wetting and drying processes (ASSIS et al., 2009).

According to Beutler et al. (2001), the PR value of $2 \mathrm{MPa}$ that is accepted as limiting to the growth of roots and shoots, has been questioned about the several crops and soil types under different management systems. An increase in coil resistance to penetration can be restrictive to the root growth when values exceed the range from 1.5 to $4.0 \mathrm{MPa}$ (SILVA et al., 2006).

In some places, compaction reduces plant productivity. More pronounced effects of this issue are observed when the soil is cultivated under crop rotation. Under elevated degrees of compaction, mechanical methods such as scarification or subsoiling are necessary, but the reduction in compaction observed in the first year after the mobilization is not observed in the following years (REINERT et al., 2008).

The practice of recovery soil compaction by biological processes way happens by using plants that help the soil to recover. They are also known as green manure or cover crops.

The bioporosity created by root activity and soil mesofauna along with the possibility of the roots of some crops penetrating more compacted layers have been the reason why crop rotation has been considered fundamental in no-tillage systems (ANDRADE et al., 2009).

Thus, practices that seek continuous and abundant supply of organic matter to the soil associated with conservation tillage methods are of fundamental importance in the recovery of physically degraded soils (PORTELA et al., 2010).

Considering that the no-tillage system is the management that induces the soil to achieve higher compaction state by the absence of disturbance combined with systematic traffic of agricultural machinery and implements in high soil moisture, it is also important to change the rotation system, by including cover crops to improve soil quality.

The objective of this study is to evaluate the potential of twelve species of cover crops in improving the structural state of the soil, by analyzing soil bulk density and resistance to penetration and the Crambe grain yield and oil content after the cover crops.

\section{MATERIAL AND METHODS}

The experiment was conducted at the Experimental Center of Agricultural Engineering (NEEA), at the State University of West Paraná (UNIOESTE), located in Cascavel - Paraná, at latitude $24^{\circ} 53^{\prime} 47^{~ " S}$ and longitude 53\%32'09" W, with average annual rainfall of $1.600 \mathrm{~mm}$ and average temperature of $19^{\circ} \mathrm{C}$. Local soil is an Oxisol, with clayey to very clayey texture, wavy terrain and basalt substrate (SANTOS et al., 2013). Local climate is 
temperate/mesothermal and super-humid, and is classified as Cfa (Koeppen).

The seeding of cover crops was conducted in December 2009 by using a seeder/fertilizer machine for plowing rows. Sowing was performed manually in the plowing lines.

The cover crops were named as treatments and consisted of twelve species, namely: Crotalaria juncea (Crotalaria juncea), Crotalaria spectabilis (Crotalaria spectabilis), Pigeon pea (Cajanus cajan), Jack bean (Canavalia ensiformis), Foxtail millet (Setaria italica), Forage sorghum (Sorghum bicolor), Lablab beans (Dolichos lab lab), Guandu beans (Cajanus cajan), Mucuna aterrimum, Mucuna Pruriens, Mucuna deeringiana, Mucuna aterrima and a control treatment (fallow area).

The experimental design used in the study consisted of randomized blocks with 4 replications and plots measuring $5 \times 5 \mathrm{~m}$.

When species were in full bloom in May 2010, they were managed via desiccation, with the use of non-selective herbicide with subsequent mowing in order to accelerate the rate of decomposition of their roots, so that we could evaluate the effect of their root system on the possible improvement of soil structure.

After the desiccation of the cover crops in November 2010, we implemented a soybean crop, which was negatively affected by severe drought. After the soybean crop, in April 2011 we implemented the first crambe crop, which was destroyed by frost during the winter. In August 2011 we implemented the second crambe crop, which we were able to analyze and assess grain and oil yield.

In January 2012, we collected soil samples for evaluation of soil bulk density using the volumetric ring method (EMBRAPA, 1997) at depths of 0.0-0.1, $0.1-0.2$ and $0.2-0.3 \mathrm{~m}$.

Soil resistance to penetration was determined with the aid of a penetrometer (Falker Penetrolog PLG 1020) with electronic data storage. Collections were performed with five sampling points in each experimental unit, up to $0.4 \mathrm{~m}$ deep.

For the determination of grain yield, we collected an area of $4 \mathrm{~m}^{2}$ in the central part of each plot. Threshing was performed manually.

In the laboratory, we removed impurities and cleaned the seeds using sieves. After cleaning, the samples were weighed in a semi-analytical balance accurate to two decimal places. Crambe oil extraction was carried out at A3Q Analysis Laboratory in Cascavel - Pr. We randomly selected 50 grams of seeds of each sample from each treatment. They were ground in order to increase the contact surface with the solvent and subjected to a drying process in an oven at $105^{\circ} \mathrm{C}$ for 24 hours so that their moisture was removed.

In order to determine seed oil content, we used the Soxhlet method, based on procedures adapted from the analytical standard of the Adolfo
Lutz Institute (PREGNOLATO; PREGNOLATO, 1985).

The seeds were ground in a portable mixer. Then $5 \mathrm{~g}$ of each sample were weighed in paper filter and transferred to the cartridge of the Soxhlet extractor. A flat-bottomed flask was connected to the extractor and $200 \mathrm{~mL}$ of hexane solvent were added. The heater plate was turned on to a constant temperature and the extraction was carried out continuously for 8 hours (four to five drops per second). Cartridges were removed and the solvent was distilled off and transferred to a flask containing the residue extracted. It was kept in an oven at $105^{\circ} \mathrm{C}$ for roughly one hour. Then, the desiccator was cooled down to room temperature and the flat-bottomed flask was weighed.

The calculation of oil content was done using the following formula: $100 \times \mathrm{N} / \mathrm{P}=$ lipids or ether extract per cent $\mathrm{m} / \mathrm{m}$

\section{Where: $\mathrm{N}=$ number of grams of lipids $\mathrm{P}=$ number of grams of sample}

Statistical analyzes for soil variables (bulk density and resistance to penetration) and plant variables (grain and oil yield) were performed by means of analysis of variance (ANOVA). Means comparison was performed using Tukey's test at 5\% probability. Data were processed in free software Sisvar version 5.3.

We also performed linear regression analyzes between data concerning to grain yield and oil yield, as well as grain yield and soil density using Excel®.

Crambe oil extraction was carried out at A3Q Analysis Laboratory in Cascavel - Pr. We randomly selected 50 grams of seeds of each sample from each treatment. They were ground in order to increase the contact surface with the solvent and subjected to a drying process in an oven at $105^{\circ} \mathrm{C}$ for 24 hours so that their moisture was removed.

In order to determine seed oil content, we used the Soxhlet method, based on procedures adapted from the analytical standard of the Adolfo Lutz Institute (PREGNOLATO; PREGNOLATO, 1985).

The seeds were ground in a portable mixer. Then $5 \mathrm{~g}$ of each sample were weighed in paper filter and transferred to the cartridge of the Soxhlet extractor. A flat-bottomed flask was connected to the extractor and $200 \mathrm{~mL}$ of hexane solvent were added. The heater plate was turned on to a constant temperature and the extraction was carried out continuously for 8 hours (four to five drops per second). Cartridges were removed and the solvent was distilled off and transferred to a flask containing the residue extracted. It was kept in an oven at $105^{\circ} \mathrm{C}$ for roughly one hour. Then, the desiccator was cooled 
down to room temperature and the flat-bottomed flask was weighed.

The calculation of oil content was done using the following formula: $100 \times \mathrm{N} / \mathrm{P}=$ lipids or ether extract per cent $\mathrm{m} / \mathrm{m}$

Where: $\mathrm{N}=$ number of grams of lipids
$\mathrm{P}=$ number of grams of sample

Statistical analyzes for soil variables (bulk density and resistance to penetration) and plant

\section{RESULTS AND DISCUSSION}

Table 1 presents the average soil density values at the 3 depths studied with 12 cover crops plus the fallow area. variables (grain and oil yield) were performed by means of analysis of variance (ANOVA). Means comparison was performed using Tukey's test at 5\% probability. Data were processed in free software Sisvar version 5.3 .

We also performed linear regression analyzes between data concerning to grain yield and oil yield, as well as grain yield and soil density using Excel®.

Table 1. Average values of soil density $\left(\mathrm{Mg} \mathrm{m}^{-3}\right)$ at three depths with twelve cover crops and fallow area (average of four replications)

\begin{tabular}{lccc}
\hline \multicolumn{1}{c}{ Cover crop } & $0-0.1$ & Depth $(\mathrm{m})$ & $0.2-0.3$ \\
\cline { 2 - 4 } Fallow & $1.25 \mathrm{Aa}$ & $0.1-0.2$ & $1.11 \mathrm{Ba}$ \\
C. Spectabillis & $1.08 \mathrm{Bb}$ & $1.19 \mathrm{Aa}$ & $1.19 \mathrm{Aa}$ \\
C. ensiformis & $1.19 \mathrm{Aab}$ & $1.23 \mathrm{Aa}$ & $1.15 \mathrm{Aa}$ \\
$M$. aterrimum & $1.15 \mathrm{Aab}$ & $1.19 \mathrm{Aa}$ & $1.15 \mathrm{Aa}$ \\
$M$. deeringiana & $1.17 \mathrm{Aab}$ & $1.17 \mathrm{Aa}$ & $1.15 \mathrm{Aa}$ \\
C. Juncea & $1.15 \mathrm{Aab}$ & $1.19 \mathrm{Aa}$ & $1.14 \mathrm{Aa}$ \\
C. cajan & $1.20 \mathrm{Aab}$ & $1.19 \mathrm{Aa}$ & $1.14 \mathrm{Aa}$ \\
$M$. Pruriens & $1.13 \mathrm{Aab}$ & $1.15 \mathrm{Aa}$ & $1.14 \mathrm{Aa}$ \\
Lablab & $1.19 \mathrm{Aab}$ & $1.17 \mathrm{Aa}$ & $1.11 \mathrm{Aa}$ \\
Setaria italica & $1.17 \mathrm{Aab}$ & $1.20 \mathrm{Aa}$ & $1.19 \mathrm{Aa}$ \\
Cajanus cajan & $1.13 \mathrm{Aab}$ & $1.13 \mathrm{Aa}$ & $1.11 \mathrm{Aa}$ \\
Sorghum & $1.16 \mathrm{Aab}$ & $1.15 \mathrm{Aa}$ & $1.12 \mathrm{Aa}$ \\
$M$. aterrima & $1.07 \mathrm{Ab}$ & $1.13 \mathrm{Aa}$ & $1.14 \mathrm{Aa}$ \\
\hline LSD line & 0.108 & & \\
LSD column & 0.155 & & \\
CV (\%) & 5.60 & &
\end{tabular}

Treatment means followed by different letters (lowercase in columns and uppercase in lines) differ from each other by Tukey's test at $5 \%$ significance.

In what concerns to soil bulk density in the first layer $(0-0.10 \mathrm{~m})$, the treatments that provided the lowest values were Crotalaria Spectabillis and Mucuna aterrima, which differed from the fallow area and were statistically similar to the other crops, reaching an average value of 1.08 and $1.07 \mathrm{Mg} \mathrm{m}^{-3}$, respectively.

As for the other layers $(0.10-0.20$ and 0.20 $0.30 \mathrm{~m})$, it was not observed any statistical differences between treatments. By analyzing the effect of treatments at the three layers studied, we verified that only in the fallow area the layer $0.20-0.30 \mathrm{~m}$ showed values lower than those of other cover crops. In the other treatments there were no significant differences between layers, except for Crotalaria Spectabillis, which showed lower values than the others at the layer $0-0.10$ $\mathrm{m}$.

There was a significant reduction of soil bulk density in all treatments when compared to the untreated area, that is, all cover crops had good features in the improvement of the structural state of the soil, what caused the reduction of bulk density, though not significantly. The species that stood out and showed significant differences in the layer $0-0.1 \mathrm{~m}$ were Crotalaria spectabillis and Mucuna aterrima (Table 1).

According to Calegari et al. (1993), Crotalaria spectabillis has a pivoting and deep root that is able to break compacted layers and that, when decomposing, favors subsequent crops, allowing the extension of their root systems though the channels produced. 
Carvalho et al. (2002) also highlight the great ability of this species to explore greater volume of soil in depth due to the biopores formed, which contribute to increasing water movement in the soil and the diffusion of gases.

The results of this research are in accordance with Nascimento et al. (2005), who studied an Alfisol under no-tillage for three years using the following cover crops: Cajanus cajan, Lablab beans, Mucuna aterrimum, Mucuna Pruriens, Crotalaria juncea and Jack bean. The authors did not observe alterations in bulk density.
Table 2 presents the average values of soil resistance to penetration (SPR).

In the first layer, there were no significant differences between the tested species. In general, this layer had the lowest values of soil resistance to penetration. This was possibly caused by mobilization of soil caused by machinery on the land and by the higher input of organic matter, which contributes to greater soil aggregation (CUNHA et al., 2007).

Table 2 - Average values of soil resistance to penetration (MPa) at four depths with twelve cover crops and fallow area (average of four replications)

\begin{tabular}{lcccc}
\hline \multirow{2}{*}{ Cover crop } & \multicolumn{3}{c}{ Depth $(\mathrm{m})$} \\
\cline { 2 - 5 } Fallow & $0-0.1$ & $0.1-0.2$ & $0.2-0.3$ & $0.3-0.4$ \\
C. Spectabillis & $2.21 \mathrm{Ba}$ & $3.57 \mathrm{Ab}$ & $2.53 \mathrm{Ba}$ & $2.16 \mathrm{Ba}$ \\
C. ensiformis & $2.21 \mathrm{Ba}$ & $3.40 \mathrm{Ab}$ & $2.41 \mathrm{Ba}$ & $2.23 \mathrm{Ba}$ \\
$M$. aterrimum & $2.11 \mathrm{Aa}$ & $2.87 \mathrm{Ab}$ & $2.28 \mathrm{Aa}$ & $2.00 \mathrm{Aa}$ \\
$M$. deeringiana & $2.09 \mathrm{Ba}$ & $3.52 \mathrm{Ab}$ & $2.46 \mathrm{Ba}$ & $2.32 \mathrm{Ba}$ \\
C. Juncea & $1.76 \mathrm{Ba}$ & $2.91 \mathrm{Ab}$ & $2.49 \mathrm{ABa}$ & $1.97 \mathrm{Ba}$ \\
C. cajan & $1.87 \mathrm{Ba}$ & $2.91 \mathrm{Ab}$ & $2.31 \mathrm{ABa}$ & $2.11 \mathrm{ABa}$ \\
$M$. Pruriens & $2.13 \mathrm{Ba}$ & $3.86 \mathrm{Ab}$ & $2.61 \mathrm{Ba}$ & $2.20 \mathrm{Ba}$ \\
Lablab & $2.45 \mathrm{ABa}$ & $3.10 \mathrm{Ab}$ & $2.11 \mathrm{Ba}$ & $2.02 \mathrm{Ba}$ \\
Setaria italica & $2.36 \mathrm{Ba}$ & $5.31 \mathrm{Aa}$ & $2.81 \mathrm{Ba}$ & $2.39 \mathrm{Ba}$ \\
Cajanus cajan & $2.41 \mathrm{Ba}$ & $3.71 \mathrm{Ab}$ & $2.50 \mathrm{Ba}$ & $2.16 \mathrm{Ba}$ \\
Sorghum & $2.06 \mathrm{Ba}$ & $2.28 \mathrm{Ab}$ & $2.76 \mathrm{ABa}$ & $2.41 \mathrm{ABa}$ \\
$M$. aterrima & $2.58 \mathrm{Ba}$ & $3.59 \mathrm{Ab}$ & $2.56 \mathrm{Ba}$ & $2.24 \mathrm{Ba}$ \\
\hline LSD line & $2.34 \mathrm{Ba}$ & $3.38 \mathrm{Ab}$ & $2.63 \mathrm{ABa}$ & $2.33 \mathrm{Ba}$ \\
LSD column & 0.89 & & & \\
CV (\%) & 1.15 & & & \\
\hline
\end{tabular}

Treatment means followed by different letters (lowercase in columns and uppercase in lines) differ from each other by Tukey's test at $5 \%$ significance. Gravimetric unit: $0-0.1 \mathrm{~m}-27 \%, 0.1-0.2 \mathrm{~m}-28 \%, 0.2-0.3 \mathrm{~m}-28 \%$ and $0.3-0.4 \mathrm{~m}-29 \%$.

Average values of grain and oil yield for all treatments, as well as their relative yields are shown in Table 3.

In the second layer, the Lablab species showed the highest average SPR value (5.31 MPa) and differed statistically from the other treatments. In the layers 0.2$0.3 \mathrm{~m}$ and $0.3-0.4 \mathrm{~m}$ we did not observe significant statistical differences between treatments.

In the layer $0.30-0.40 \mathrm{~m}$ all treatments were considered statistically similar. Genro Júnior et al. (2009) did not observe positive effect on SPR reduction throughout three years using cover crops.

In all treatments, the layer that showed the highest SPR results was $0.10-0.20 \mathrm{~m}$. This layer is the one that suffers most with deformation when it comes to no-tillage due to the use of machinery on the land in inadequate conditions. This result is in accordance with Silva et al. (2000), who obtained the highest values of soil resistance to penetration in the layer $0.07-0.17 \mathrm{~m}$ under no-tillage. Tormena et al. (2004) observed higher values up to roughly $0.15 \mathrm{~m}$ of depth.

No statistical differences between treatments were found in what concerns to yield and relative grain yield, possibly due to the high variability found between replications of a same treatment as the coefficient of variation (CV) exceeded 30\%. Figure 1 shows the linear correlation between crambe grain yield and oil content. 
REVISTA SCIENTIA AGRARIA

Versão On-line ISSN 1983-2443

Versão Impressa ISSN 1519-1125

SA vol. $19 \mathrm{n}^{\circ} .1$ Curitiba Jan/Mar 2018 p. 160-167

Table 3 - Crambe grain yield and oil content and relative yield after the use of 12 cover crops and fallow area (average of 4 replications)

\begin{tabular}{|c|c|c|c|c|}
\hline Cover crop & $\begin{array}{c}\text { Grain yield }\left(\mathrm{kg} \mathrm{ha}^{-}\right. \\
1)\end{array}$ & $\begin{array}{c}\text { Relative yield } \\
\text { (grains) }(\%)\end{array}$ & $\begin{array}{l}\text { Oil yield Grain } \\
\text { yield }\left(\mathrm{kg} \mathrm{ha}^{-1}\right)\end{array}$ & Relative yield (oil) (\%) \\
\hline Fallow & 490 & 100 & 104 & 100 \\
\hline C. Spectabillis & 604 & 123 & 133 & 128 \\
\hline C. ensiformis & 596 & 122 & 123 & 118 \\
\hline M. aterrimum & 553 & 113 & 127 & 122 \\
\hline M. deeringiana & 775 & 158 & 173 & 166 \\
\hline C. Juncea & 666 & 136 & 153 & 147 \\
\hline C. cajan & 655 & 134 & 160 & 154 \\
\hline M. Pruriens & 696 & 142 & 154 & 148 \\
\hline Lablab & 755 & 154 & 175 & 168 \\
\hline Setaria italica & 596 & 122 & 125 & 120 \\
\hline Cajanus cajan & 800 & 163 & 191 & 184 \\
\hline Sorghum & 734 & 150 & 176 & 169 \\
\hline M. aterrima & 730 & 149 & 162 & 156 \\
\hline LSD & 675 & & 171 & \\
\hline $\mathrm{CV}(\%)$ & 40,33 & & 45,58 & \\
\hline
\end{tabular}

There were no statistical differences between treatments by Tukey's test at 5\% significance.

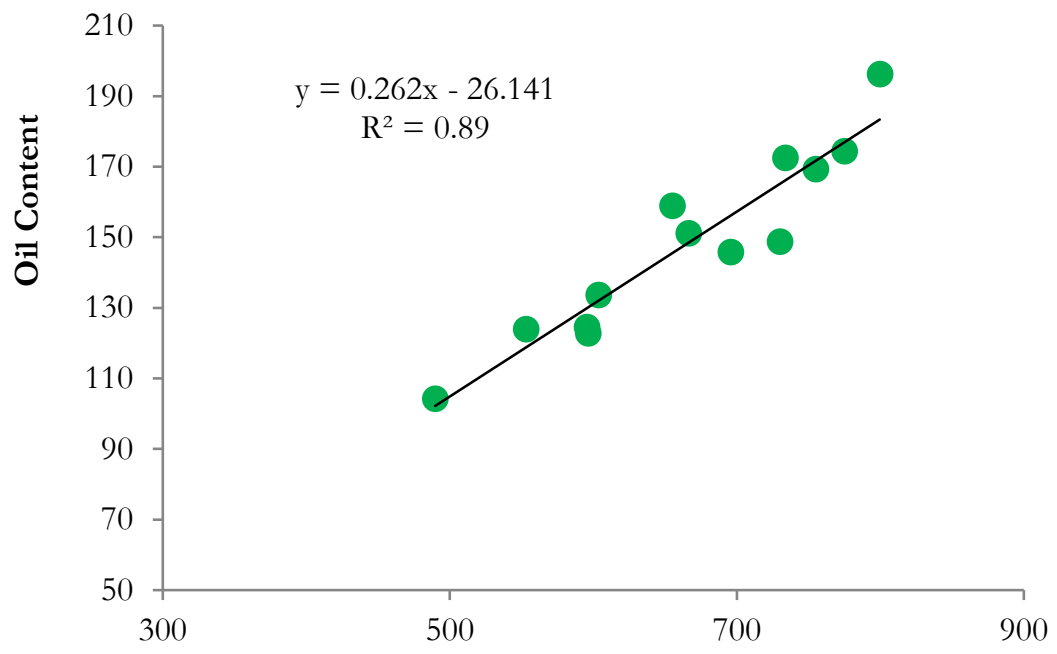

Grain yield

Figure 1 - Linear correlation between crambe grain yield $\left(\mathrm{kg} \mathrm{ha}^{-1}\right)$ and oil content $\left(\mathrm{kg} \mathrm{ha}^{-1}\right)$.

Oil content of crambe is influenced by grain yield in a linear way in $89 \%\left(\mathrm{R}^{2}=0.89\right)$, what shows that there is a good relation between both variables. This result is contrary to that achieved by Lunelli (2012), who obtained a weak linear explanation of only $3.8 \%$ between crambe grain yield and oil yield. Figure 2 shows the Linear correlation between soil density and grain yield.
There is low correlation between these variables, $49 \%\left(\mathrm{R}^{2}=0.49\right)$, what implies a low correlation between soil bulk density associated with crambe grain yield. That indicates that this range of bulk density (1.1-1.2 $\left.\mathrm{Mg} \mathrm{ha}^{-1}\right)$ did not alter crambe grain yield. 


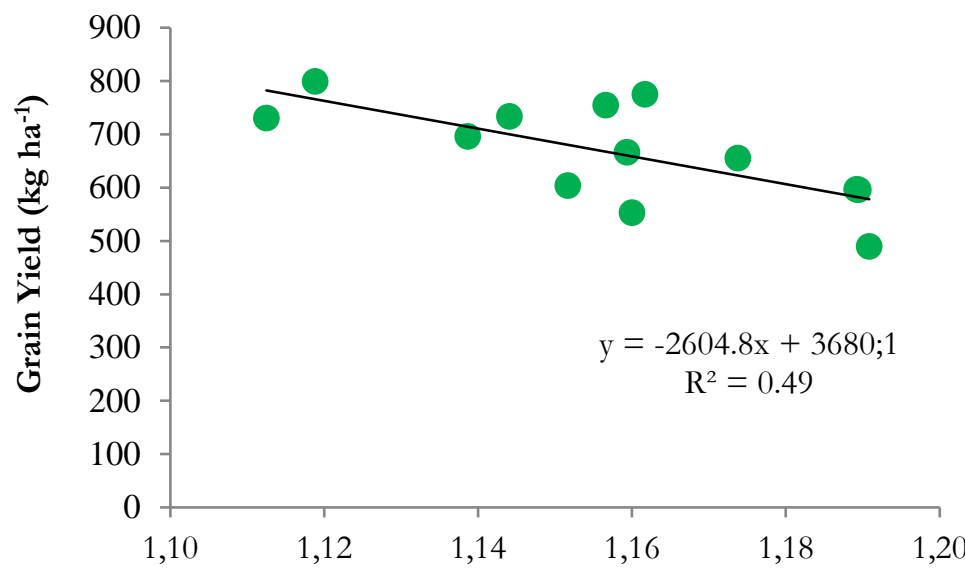

Soil bulk density

Figure 2. Linear correlation between soil density and grain yield.

\section{CONCLUSION}

Considering the structural state of the soil prior to the experiment, with density values lower than $1.2 \mathrm{Mg} \mathrm{m}^{-3}$, there was no significant effect on soil structure by any of the cover crops used.

Cover crops did not statistically influence the yield of grains and crambe oil

\section{REFERENCES}

ANDRADE, R.S.; STONE, L.F.; SILVEIRA, P.M. Culturas de cobertura e qualidade física de um Latossolo em plantio direto. Revista Brasileira de Engenharia Agrícola e Ambiental, Campina Grande, v. 13, n. 4, Aug. 2009.

ASSIS, R.L.; CARGNELUTTI FILHO, A.; LANÇAS, K.P.; LAZARINI, G.D. Avaliação da resistência do solo à penetração em diferentes solos com a variação do teor de água. Engenharia Agrícola, Jaboticabal, v. 29, ก. 4, 2009

BEUTLER, A.N.; SILVA, M.L.N.; CURI, N.; FERREIRA, M.M.; CRUZ, J.C.; PEREIRA FILHO, I.A. Resistência à penetração e permeabilidade de Latossolo Vermelho distrófico típico sob sistemas de manejo na Região dos Cerrados. Revista Brasileira de Ciência do Solo, Viçosa, v.25, p.167-177, 2001.

CALEGARI, A.; MONDARDO, A.; BULISANI, E.A ; WILDNER, L.P.; COSTA, M. B.; ALCÂNTARA, P. B.; MIYASAKA, S.; AMADO, T.J.C. Adubação verde no Sul do Brasil. Rio de Janeiro, $2^{\mathrm{a}}$ edição, 1993, 346 p.
CARVALHO, S. R. L. de; REZENDE, J. O; FERNANDES, J. C.; PEREIRA, A, P. Caracterização e avaliação de leguminosas e gramíneas com alto poder relativo de penetração de raízes em solo coeso dos tabuleiros costeiros do recôncavo baiano - ETAPA I. Magistra, Cruz das Almas, v. 14, n. 1, 2002.

CUNHA, E. Q., BALBINO, L. C., STONE, L. F., LEANDRO, W. M. AND OLIVEIRA, G. C. 2007. Influência de rotações de culturas nas propriedades físico- hídricas de um Latossolo Vermelho em plantio direto. Engenharia Agrícola, Jaboticabal, v. 27, p.665674, 2007.

EMBRAPA: EMPRESA BRASILEIRA DE PESQUISA AGROPECUÁRIA. Manual de métodos de análise de solo. Centro Nacional de Pesquisa de Solos. Rio de Janeiro: EMBRAPA CNPS, 1997. 212p.

GENRO JUNIOR, S.A., REINERT, D.J., REICHERT, J.M.; ALBUQUERQUE, J. A. Atributos físicos de um Latossolo Vermelho e produtividade de culturas cultivadas em sucessão e rotação. Ciência Rural, v.39, p.65-73, 2009.

GENRO JUNIOR, S. A.; REINERT, D. J.; REICHERT, J. M.. Variabilidade temporal da resistência à penetração de um latossolo argiloso sob semeadura direta com rotação de culturas. Revista Brasileira de Ciência do Solo, Viçosa, v.28, n.3, 2004.

GUARIZ, H. R.; PICOLI, M.H.S.; CAMPANHARO,W.A.; CECÍLIO, R.A. Variação da Umidade e da Densidade do Solo sob Diferentes Coberturas Vegetais. Revista Brasileira de Agroecologia, Cruz Alta, v.4, n. 2, p.3293-3296, 2009. 
LUNELLI, I.E. Efeitos de arranjos nutricionais de NPK na produtividade de grãos e rendimento de óleo da cultura do crambe. Dissertação de Mestrado em Energia na Agricultura - Universidade Estadual do Oeste do Paraná, Cascavel, 2012.

NASCIMENTO, J. T., SILVA, I. F., SANTIAGO, R. S. AND NETO, L. F. S. Efeito de leguminosas nos atributos físicos e carbono orgânico de um Luvissolo. Revista Brasileira de Ciência do Solo, Viçosa, v.29, p.825-831, 2005.

NASCIMENTO, J.T.; SILVA, I.F., SANTIAGO, R.D.; SILVEIRA NETO, L.F.S. Efeito de leguminosas nas características químicas e matéria orgânica de um solo degradado. Revista Brasileira de Engenharia Agrícola e Ambiental, Campina Grande, v.7, n.3, 2003.

PORTELA, J.C.; COGO, N.P.; BAGATINI, T.; CHAGAS, J.P.; PORTZ, G. Restauração da estrutura do solo por sequencias culturais implantadas em semeadura direta, e sua relação com a erosão hídrica em distintas condições físicas de superfície. Revista Brasileira de Ciência do Solo, Viçosa, v.34 p.1353-1364, 2010

PREGNOLATO, W.; PREGNOLATO, N.P. Normas Analíticas do Instituto Adolfo Lutz: métodos químicos e físicos para análise de alimentos, $3^{\text {a }}$ Edição, São Paulo: Instituto Adolfo Lutz, 1985.

REINERT, D.J.; ALBUQUERQUE, J.A.; REICHERT, J.M.; AITA, C.; ANDRADA, M.M.C. Limites críticos de densidade do solo para o crescimento de raízes de plantas de cobertura em argissolo vermelho. Revista Brasileira de Ciência do Solo, Viçosa , v.32, n.5, 2008.

SANTOS, H.G.; JACOMINE, P.K.T.; ANJOS, L. H.C.; OLIVEIRA, V. A.; LUMBRERAS, J. F.; COELHO, M. R.; ALMEIDA, J. A.; CUNHA, T. J. F.; OLIVEIRA, J. B. de. Sistema brasileiro de classificação de solos. 3. ed. rev. e ampl. Brasília, DF: Embrapa, 2013. 353 p.

SILVA, S.R.; BARROS, N.F.; COSTA, L.M. Atributos físicos de dois Latossolos afetados pela compactação do solo. Revista Brasileira de Engenharia Agrícola e Ambiental, Campina Grande, v.10, n.4, 2006.

SILVA, V. R., REINERT, D. J.; REICHERT, J. M. Resistência mecânica do solo à penetração influenciada pelo tráfego de uma colhedora em dois sistemas de manejo do solo. Ciência Rural, Santa Maria, v.30, p.795801, 2000.
TORMENA, C.A.; FRIEDRICH, R.; PINTRO, J.C.A.; COSTA, C.S.; FIDALSKI, J. Propriedades físicas e taxa de estratificação de carbono orgânico num Latossolo Vermelho após dez anos sob dois sistemas de manejo. Revista Brasileira de Ciência do Solo, Viçosa, v.28, p.1023-1031, 2004. 